\title{
The application of factor analysis method in performance evaluation of
}

\section{listed banking business}

\author{
Xin Ling Du ${ }^{1, a}$ and Shu Jia Chen ${ }^{1, b^{*}}$ \\ 1Beijing Normal University Zhuhai Campus, Zhuhai 519087, China \\ "Corresponding Author, Shu Jia Chen \\ aemail,du_xinling2008@163.com,'email, imsoga@hotmail.com
}

Keywords: Listed bank; Performance evaluation; Factor analysis; Market structure; Banking scale

\begin{abstract}
Bank is the core of modern financial industry, and its development trend is related to the operation of the whole national economy. Bank efficiency and the level of bank performance are important factors affecting a country's economic security. Therefore, the performance of listed banks is the key issue of financial industry. In this paper, the performance level of 16 listed banks of China is analyzed with demonstration in the year of 2013. The paper evaluates the performance of listed banking business with factor analysis method by picking 11 indexes, and offers relevant countermeasures and suggestions.
\end{abstract}

\section{Introduction}

The discussion on the performance evaluation of banking industry has never ended since the application of DEA model in the bank performance through cost and profit by Farrell in 1957. For example, the Du Pont financial analysis system was applied into banking system in 1972; the FED founded more accurate CAMEL evaluation system in 1979.

The research on the performance evaluation of banking industry began relatively late in China. Sun Jing (2009) ${ }^{[1]}$ studied and analyzed the status quo of the performance evaluation system in western commercial bank; it's concluded that the performance evaluation system of western commercial bank is designed for regulators so far with the purpose of ensuring the financial stability and safety coefficient. Yang En $(2010)^{[2]}$ drew the conclusion from analyzing the comprehensive performance of 14 Chinese listed banks that, from 2001 to 2008, the state-owned commercial banks was optimal in comprehensive performance, then the joint-stock commercial banks and city commercial banks with relatively worst performance; Tang Jinfeng (2012) ${ }^{[3]}$ came to a conclusion through studying the relation of ownership structure and economic value added (EVA) of listed banks that there is a negative correlation relationship for the shareholding ratio in state-own shareholders and listed banks EVA, and positive correlation relationship in different degrees for the shareholding ratio in shareholders of public shares and corporate shares.

At present, the main performance evaluation methods of listed banks are Du Pont Approach, Economic Value Added (EVA), Balance Scorecard and Factor analysis.

\section{The influencing factors for the performance evaluation of listed banks}

Market structure. Bank market structure can be summarized as market share and concentration of 
each bank; it reflects the inner link of various elements between provider and demander in the market.

Bank scale. Bank scale includes total assets, total liabilities, savings and loan scale, the intermediary business scale, the number of employees and number of branches, etc.

Business principles.The business principles of bank can be summed up as "security", "profitability", and "liquidity, which has a strong relationship and influence the bank performance in different degrees.

\section{The construction of performance evaluation indexes system in the listed banking industry}

In 2000, People's Bank of China designed <tentative method for commercial banks performance evaluation>, including 13 indexes; in 2004, the China Banking Regulatory Commission issued < the "rural financial institutions risk assessment and warning indexes system (for trial) >, including 17 indexes. The principles of constructing the performance evaluation indexes system of listed Chinese banks are: comprehensiveness, authenticity, importance, objectivity and availability of data.

According to the factors which influence the listed bank performance, the paper chooses 11 indexes in four aspects reflecting the business performance such as market share capability, size, profitability and operation capacity, safety and growth; the market structure is mainly reflected in the market share capability, and the specific index is the ratio of net profit and ratio of total assets; the bank size is reflected by the three indexes: total debt ratio, deposit ratio and loan ratio; profitability and operation capacity is mainly shown as the earnings, and the two indexes are return on weighted assets and return on assets; safety shows its ability to avoid risks, and the two indexes are capital adequacy ratio and loan-deposit ratio; the growth includes growth rate of total assets and net profit.

The 11 indexes are expressed by the variables $x_{1}, x_{2}, x_{3}, x_{4}, x_{5}, x_{6}, x_{7}, x_{8}, x_{9}, x_{10}$ and $x_{11}$

\section{Research methods and data sources}

The paper adopts factor analysis of multivariate statistics analysis method for the performance evaluation of listed banks.

Research object is the 16 listed Chinese banks, and data comes from the annual financial statement of 2013 released by Sina Financial Network. The 16 listed banks are: Industrial and Commercial Bank of China(ICBC), China Construction Bank(CBC), Bank of China(BOC), Agricultural Bank of China(ABC), Bank of Communications(BOCOM), China Merchants Bank(CMB), Shanghai Pudong Development Bank(SPDB), China Minsheng Banking Corp. Ltd(CMBC), Industrial Bank Corp. Ltd, Ping An Bank, Nanjing Bank, Bank of Ningbo, China Citic Bank, China Everbright Bank(CEB), Bank of Beijing, Hua Xia Bank(HXB). The original data involving each bank's 11 financial indexes omits as the same dimension of each index, so there is no need for standardizing the index. As to one of the missing deposit-lending ratio of China Minsheng Banking Corp. Ltd and Industrial Bank Corp. Ltd, the mean of other years' ratio will substitute it; as to partial inverse indexes, direct indexes are achieved through reciprocal. 


\section{Empirical analysis of listed banks performance evaluation in China}

Validity analysis. The underlying premise of factor analysis is the relevant relations among the original variables. Using KMO (Kaiser-Meyer-Olkin) and Bartlett's test of Sphericity, the value of KMO statistics is from 0 to 1 , the more close to 1 of $\mathrm{KMO}$ value indicates the more common factors of variables, and the more suitable for factor analysis. According to the view of scholars Kaiser (1974), factor analysis requires KMO coefficient to be at least 0.6 and above ${ }^{[5]}$. SPSS20 software conducts KMO test and spherical Bartlett test; KMO coefficient is 0.600 in table 1, and Sig. is 0.000 in Bartlett spherical inspection, which means the significant correlation, so the selected samples are suitable for factor analysis.

Table 1 KMO and Bartlett's Test

\begin{tabular}{|c|c|c|}
\hline \multicolumn{2}{|c|}{ Kaiser-Mayer-Olkin Measure of Samplings Adequacy. } & 600 \\
\hline \multirow{3}{*}{ Bartlett's Test of Sphericity } & Approx. Chi-Square & 305.502 \\
\hline & df & 55 \\
\hline & Sig. & .000 \\
\hline
\end{tabular}

Calculating eigenvalue, proportion of eigenvalue and cumulative. The extract of factor adopts principal component analysis; the dimension reduction of variables is achieved through linear combination of original variables and solution of each principal component. The steps of coefficient solution to mathematical model of principal component are as follows: standardizing the data of original variables; calculating the eigenvalue of matrix $\mathrm{R}$ which is the relevant coefficient of variables, and corresponding eigenvector. Select the number of factors according to the eigenvalue and corresponding loading matrix of eigenvector calculating factors. In general, the number of factors is the same as the number of eigenvalue that the percent of cumulative contribution of variance bigger than $85 \%$ after rotating.

Table 2 Total Variance Explained

\begin{tabular}{|c|c|c|c|c|c|c|}
\hline \multirow{2}{*}{ Component } & \multicolumn{3}{|c|}{ Initial eigenvalues } & \multicolumn{3}{|c|}{$\begin{array}{c}\text { Rotation Sums of Squared } \\
\text { Loadings }\end{array}$} \\
\cline { 2 - 6 } & Total & \% of Variance & $\begin{array}{c}\text { Cumulative } \\
\%\end{array}$ & Total & $\begin{array}{c}\% \text { of } \\
\text { Variance }\end{array}$ & $\begin{array}{c}\text { Cumulative } \\
\%\end{array}$ \\
\hline 1 & 6.757 & 61.424 & 61.424 & 6.649 & 60.446 & 60.446 \\
2 & 1.732 & 15.743 & 77.167 & 1.625 & 14.773 & 75.219 \\
3 & 1.019 & 9.268 & 86.435 & 1.234 & 11.216 & 86.435 \\
4 & .845 & 7.685 & 94.120 & & & \\
5 & .482 & 4.385 & 98.504 & & & \\
6 & .122 & 1.107 & 99.612 & & & \\
7 & .034 & .308 & 99.920 & & & \\
8 & .007 & .062 & 99.982 & & & \\
9 & .001 & .012 & 99.994 & & & \\
10 & .001 & .006 & 100.000 & & & \\
11 & $1.999 \mathrm{E}-006$ & $1.817 \mathrm{E}-005$ & 100.000 & & & \\
\hline
\end{tabular}


The is as high as $86.435 \%$, bigger than $85 \%$, showing that it's proper to extract three common factors, which means the three common factors cover all the information to be expressed by all the indexes, so it's proper to evaluate the performance of the 16 listed banks. The percent of for the first factors is $60.446 \%$, which means the strongest capacity; the percents of cumulative contribution of variances for the second and the third factors are $14.773 \%$ and $11.216 \%$ separately.According to Rotated Component Matrix, it is concluded that the factor analysis model of listed bank performance drawn

$$
\left\{\begin{array}{c}
x_{1}=\alpha_{11} F_{1}+\alpha_{12} F_{2}+\cdots+\alpha_{1 m} F_{m}+\varepsilon_{1} \\
x_{2}=\alpha_{21} F_{1}+\alpha_{22} F_{2}+\cdots+\alpha_{2 m} F_{m}+\varepsilon_{2} \\
\cdots \quad \cdots \quad \cdots \\
x_{p}=\alpha_{p 1} F_{1}+\alpha_{p 2} F_{2}+\cdots+\alpha_{p m} F_{m}+\varepsilon_{p}
\end{array}\right.
$$

also

$$
\left\{\begin{array}{ccc}
x_{1}=0.984 F_{1}+(-0.080) & F_{2}+(-0.022) & F_{m}+\varepsilon_{1} \\
x_{2}=0.977 F_{1}+(-0.094) & F_{2}+(-0.051) & F_{m}+\varepsilon_{2} \\
\ldots & \ldots & \ldots \\
x_{11}=(-0.048) & F_{1}+0.173 F_{2}+0.658 F_{3}+\varepsilon_{11}
\end{array}\right.
$$

The factor analysis model shows that the first factor F1 has a larger load on net profit ratio, deposit and loan ratio, total debt ratio, total assets ratio, return on assets and capital adequacy ratio. Most of these indexes indicate the bank market share capacity and scale, so the first factor is named as the factor of bank scale and market share capacity; the second factor F2 has a larger load on deposit and loan ratio and total assets growth rate, so the second factor can be named as the factor of safety and growth; the third factor F3 has a larger load on weighed return on net assets and net profit growth rate, so the third factor can be named as profit ability factor.

Calculate the scores of factors. The composite score of the performance of the banks, represented by $\mathrm{F}$, is calculated by weighting and summary according to the proportion of the variance contribution rates of each factor to the total variance contribution rates of the three factors, namely

$$
\mathrm{F}=\left(60.446 \times \mathrm{F}_{1}+14.773 \times \mathrm{F}_{2}+11.216 \times \mathrm{F}_{3}\right) / 86.435
$$

The scores of three factors for each bank and composite scores are shown in the table 3

Table 3 Performance ranking of listed banks in 2013

\begin{tabular}{|c|c|c|c|c|c|c|c|c|}
\hline & F1 & Ranking & F2 & Ranking & F3 & Ranking & F & $\begin{array}{c}\text { Total } \\
\text { Ranking }\end{array}$ \\
\hline ICBC & 10.23 & 14 & 42.85 & 14 & 15.31 & 3 & 16.46 & 14 \\
\hline CBC & 10.99 & 10 & 45.71 & 9 & 15.77 & 1 & 17.55 & 9 \\
\hline BOC & 10.81 & 13 & 46.52 & 6 & 15.58 & 2 & 17.54 & 10 \\
\hline ABC & 10.83 & 12 & 40.26 & 16 & 13.82 & 11 & 16.24 & 15 \\
\hline BOCOM & 10.14 & 15 & 48.09 & 4 & 15.21 & 4 & 17.28 & 12 \\
\hline CMB & 13.11 & 4 & 50.21 & 2 & 14.58 & 5 & 19.65 & 3 \\
\hline SPDB & 13.52 & 3 & 48.97 & 3 & 14.42 & 7 & 19.70 & 2 \\
\hline
\end{tabular}




\begin{tabular}{|c|c|c|c|c|c|c|c|c|}
\hline CMBC & 10.04 & 16 & 40.84 & 15 & 14.41 & 8 & 15.87 & 16 \\
\hline $\begin{array}{c}\text { Industrial Bank } \\
\text { Corp. }\end{array}$ & 12.61 & 5 & 45.22 & 11 & 13.986 & 10 & 18.36 & 6 \\
\hline Ping An Bank & 11.52 & 9 & 46.492 & 7 & 13.20 & 15 & 17.72 & 8 \\
\hline Nanjing Bank & 11.89 & 8 & 43.41 & 13 & 13.02 & 16 & 17.42 & 11 \\
\hline Bank of Ningbo & 13.60 & 2 & 45.94 & 8 & 13.30 & 14 & 19.09 & 4 \\
\hline China Citic Bank & 14.89 & 1 & 51.05 & 1 & 14.39 & 9 & 21.00 & 1 \\
\hline CEB & 10.89 & 11 & 44.80 & 12 & 14.56 & 6 & 17.16 & 13 \\
\hline Bank of Beijing & 12.33 & 7 & 47.37 & 5 & 13.74 & 12 & 18.50 & 5 \\
\hline Hua Xia Bank & 12.48 & 6 & 45.38 & 10 & 13.66 & 13 & 18.26 & 7 \\
\hline
\end{tabular}

\section{Analysis of empirical findings}

F1 is the factor of bank scale and market share capacity, and the top-ranked banks are China Citic Bank, Bank of Ningbo, Shanghai Pudong Development Bank, China Merchants Bank, Industrial Bank Corp. Ltd, Hua Xia Bank; F2 is the factor of safety and growth, and the top-ranked banks are China Citic Bank, China Merchants Bank, Shanghai Pudong Development Bank, Bank of Communications, Bank of Beijing, Bank of China; F3 is the factor of profit ability, and the top-ranked banks are China Construction Bank, Bank of China, Industrial and Commercial Bank of China, Bank of Communications, China Merchants Bank, China Everbright Bank, etc. The state-owned banks are highly valued on the third factor.

According to the comprehensive ranking, the joint-stock commercial banks such as China Citic Bank, Shanghai Pudong Development Bank and China Merchants Bank are at the top, next is the Bank of Ningbo, Bank of Beijing, Industrial Bank Corp. Ltd, which indicates the joint-stock commercial banks have great advantage of competition: leading retail finance and new firms finance business; continuously optimized business structure and rapid growth of value customers; innovative electronic channels and information technology platform.

China Citic Bank establishes itself as the leading bank in the retail finance business earlier, continuously speeds up the change and innovation, accumulates systematic competitive advantages in many ways, such as product, customer, channel, brand, service, team, etc. What' more, the key indexes such as profit contribution, proportion of high-end customers, replacement rate of electronic bank counter remain a leading position in the business; constantly improve and adjust the business strategy, and obvious advantages in business structure achieves faster growth for value customers; innovative online bank and remote bank is effective complement for physical channels and actively explore the development of mobile finance.

China Citic Bank has established and strengthened the risk management system in terms of asset management and loan risk management; increase the intensity of specialization operation risk management training, and no major operation risk in 2013; establish assessment system internally, optimize the capital allocation in various agencies, product and industry, strengthen the bad assets accountability mechanism, and ensure the stability of assets quality. 


\section{Conclusion}

In conclusion, the comprehensive ability of state-owned commercial banks ranks relatively low than joint-stock commercial banks among listed banks in China. The joint-stock commercial banks have advantages on products, system innovation and operation ability. What's more, the profit and growth ability is relatively stronger. Therefore, Chinese listed banks need innovation on operation, product launch, and management system, drawing lessons from joint-stock commercial banks and banks of developed countries, decreasing intermediate links and cost, so as to be in an invincible position and achieve fast growth of net profit.

\section{References}

[1] J. Sun: World Economic outlook, (2009) No.3, p.50

[2] E. Yang: Hainan finance, (2010) No.7, P24

[3] J.F. Tang: Empirical study on the influence of listed banks ownership structure on EVA (Ph. D., Nanjing University of Finance, China 2012), p.41.

[4] K. Wei and X.W. Hu: Operation and management, (2013) No.2, p91

[5] H. F. Kaiser: Psychometrika, vol.39 (1974) No.1, p.31

[6] Y. Li: Guang Xi finance study, (2008) No.5, p.54

[7] http://quotes.money.163.com/f10/ggmx_600036_1338552.html

[8] http://quotes.money.163.com/f10/ggmx_601998_1335395.html

[9] Z.B. Zhan: Communication of Finance and Accounting, (2011) No.11, p.102

[10] W. Huang: Times Finance, (2012) No.2, p.171 